\title{
Collection and Cultivation of Swietenia macrophylla King
}

\author{
Umesh B Telrandhe ${ }^{1 *}$, Satish B. Kosalge ${ }^{2}$, Shweta Parihar ${ }^{3}$ Devender Sharma ${ }^{4}$, S. Hemalatha
}

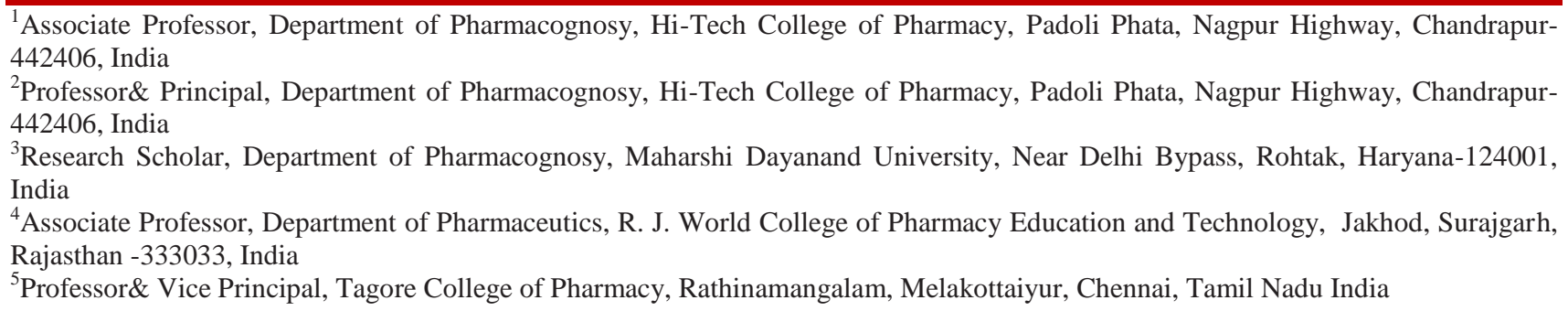

DOI: $10.36347 /$ sajp.2022.v11i01.003

| Received: 07.12.2021 | Accepted: 11.01.2022 | Published: 16.01.2022

*Corresponding author: Umesh B Telrandhe

Associate Professor, Department of Pharmacognosy, Hi-Tech College of Pharmacy, Padoli Phata, Nagpur Highway, Chandrapur442406, India

\section{Abstract}

\section{Review Article}

Meliaceae is a family of 50 genera with 1400 species that are predominantly found in tropical parts of the third world. Because of its timber and calorific value, members of this family are commercially valuable. Mahogany is a Meliaceae family exotic plant that includes three species: Swietenia macrophylla king, S mahogany L. Jacq., and S. humulis Zucc. Mahogany's distribution in India is limited to the Western and Eastern Ghats. This genus is predominantly found in the humid zone of the New World and the Amazon region of South America. The purpose of this review article is to look at its botanical description, geographical distribution, ecological range, cultivation and collection methods, wood characteristics, wood uses, therapeutic uses, seed cultivation and propagation practices, and wood characteristics, wood uses, and therapeutic uses.

Keywords: Swietenia macrophylla King, Geographical Distribution, Ecological Range, Cultivation, Collection Methods, Wood Characteristics.

Copyright (C) 2022 The Author(s): This is an open-access article distributed under the terms of the Creative Commons Attribution 4.0 International License (CC BY-NC 4.0) which permits unrestricted use, distribution, and reproduction in any medium for non-commercial use provided the original author and source are credited.

\section{INTRODUCTION}

Plants, in addition to playing an important part in photosynthesis, are a source of numerous phytochemicals, which are employed in a variety of herbal treatments and meals with healing characteristics to help mankind maintain its health. As a result, pharmaceutical product development demands a thorough examination of medicinal plants in order to improve our understanding of their biological activities and the phytoconstituents responsible for them. Furthermore, the fact that only a small number of medicinal plant species have undergone thorough scientific examination highlights the necessity for further research in this area. Plants having a long history of ethnomedicine use can provide a wealth of compounds for the treatment of a variety of chronic and infectious ailments (Sahgal et al., 2009). Many weeds in our environment are highly effective medicinal plants that can help with a variety of significant health issues (Parihar and Sharma, 2021; Chaudhary et al., 2021;
Telrandhe et al., 2021). India has long been known as a great store of natural remedies among ancient cultures (Parihar and Sharma, 2021; Parihar and Sharma, 2021; Parihar and Sharma, 2021).

The Meliaceae family includes the species Swietenia macrophylla. S. macrophylla can be found primarily in open rain forests, semideciduous woods, and deciduous forests (which lose their leaves in a partial way or total respectively, during the dry season). The particular name 'macrophylla' originates from the Greek words' macros' (big) and 'phyllon' (leaf) (leaf). Because its fruit appears to point upwards to the sky, it is frequently referred to as "sky fruit." Swietenia macrophylla is found in over 40 countries, including Brazil, Bolivia, Mexico, Guatemala, Peru, and other nations in Central America. Macrophylla trees are normally taller than 30 metres, with a straight trunk and a cylindrical trunk measuring 100 to $200 \mathrm{~cm}$ at breast height. The bark has a deep reddish brown colour, 
completely rosy, thick, and furrowed. The leaves are alternating, with leaflets opposing each other or swapped on occasion. The panicles of tiny yellowcream coloured blooms. The fruit is woody and consists of a capsule that is ovoid in shape and light brown in colour, opening on five sides and containing 10 to 14 winged seeds (Ahmad et al., 2013, Mayur et al., 2011).

Many species in this family have been used in traditional medicine to cure a variety of ailments as well as for pest control 3. This economically valuable wood tree has long been used to cure a variety of ailments, including high blood pressure, diabetes, and hypertension. Scientific studies have found that the crude extract from S. macrophylla seeds has antibacterial (Mohammaed et al., 2014; Geetha et al., 2009), anti-malaria, anti-hepatitis (Pallab et al., 2011), anti-diarrheal(Anup et al., 2007), antioxidant, antidiabetic (Moumita et al., 2011), anti-inflammatory, anti-mutagenic, antinociceptive, and anticancer properties, immunomodulatory (Otake et al., 1995; Matsuse et al., 1995) antimicrobial properties (Ayyappadhas et al., 2012).

\section{BOTANICAL DESCRIPTION}

The outer bark of older trees is scaly, shaggy, deeply longitudinally furrowed and brownish-grey to reddish-brown, and the inner bark is red-brown or pinkish-red.

The leaves are usually paripinnate, sometimes imparipinnate, $12-45 \mathrm{~cm}$ long, and are made up of 3-6 pairs of lanceolate or ovate leaflets.

The leaflets are asymmetrical, 5-12 cm long and 2-5 cm wide, with a whole margin and an acute or acuminate apex, slightly oblique and light green or reddish when young, dark green and shining when mature.

The flowers are unisexual, $0.5-1.0 \mathrm{~cm}$ in length, and are borne in large, branched inflorescences including both male and female.

The fruits are capsular, oblong or ovoid, 11.6$38.7 \mathrm{~cm}$ in length, $6.7-12.0 \mathrm{~cm}$ in diameter and light grey to brown with 4-5 valves. Each fruit contains 2271 developed seeds.

The seeds are samaroid, bulky at their base, 7$12 \mathrm{~cm}$ long and $2-2.5 \mathrm{~cm}$ wide including the wing.

(https://en.wikipedia.org/wiki/Swietenia_macr ophylla) ("The Plant List: A Working List of All Plant Species". Retrieved 20 December 2014). Figure No.1 showed Swietenia macrophylla trees. Figure No.2 showed Bark of Swietenia macrophylla trees. Figure No. 3 showed Brown fruit of Swietenia macrophylla trees. Figure No. 4 showed Capsule of Swietenia macrophylla trees (Internal arrangement of winged seeds). Figure No. 5 showed Seeds of Swietenia macrophylla trees.

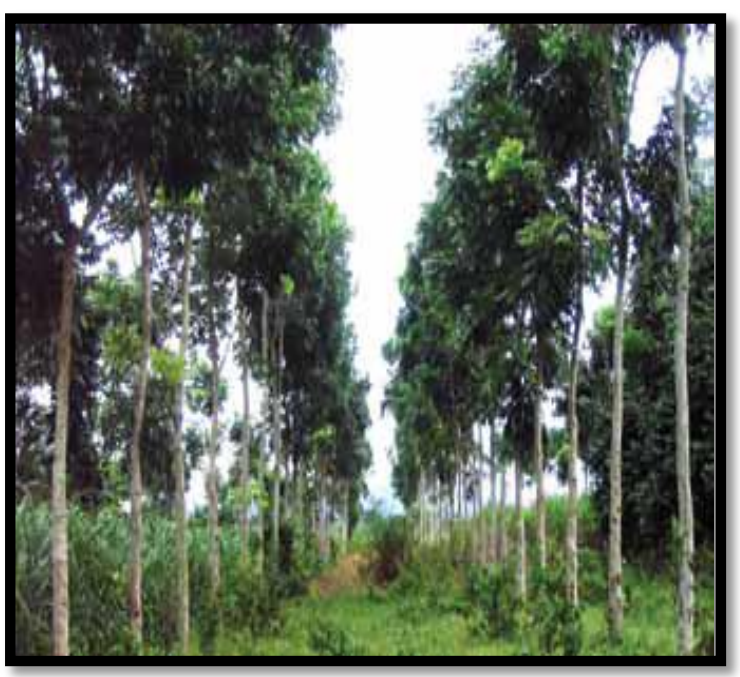

Fig-1: Swietenia macrophylla trees

(https://en.wikipedia.org/wiki/Swietenia_macrophylla)

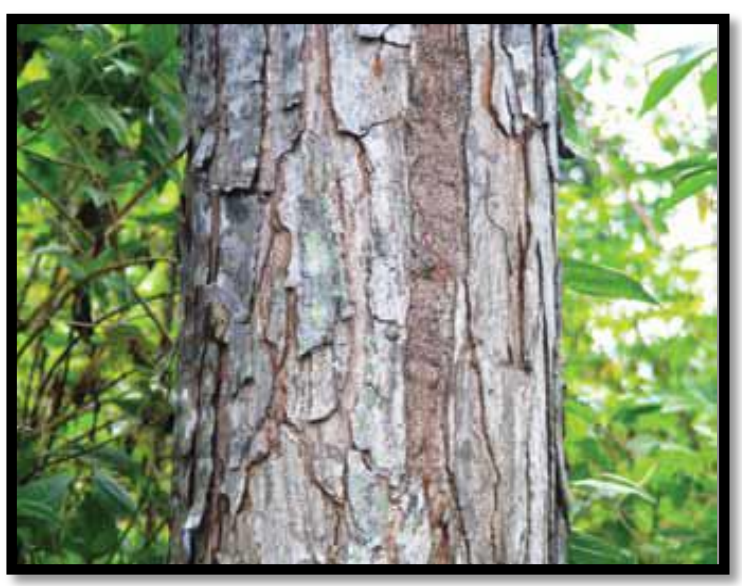

Fig-2: Bark of Swietenia macrophylla trees (https://en.wikipedia.org/wiki/Swietenia_macrophylla)

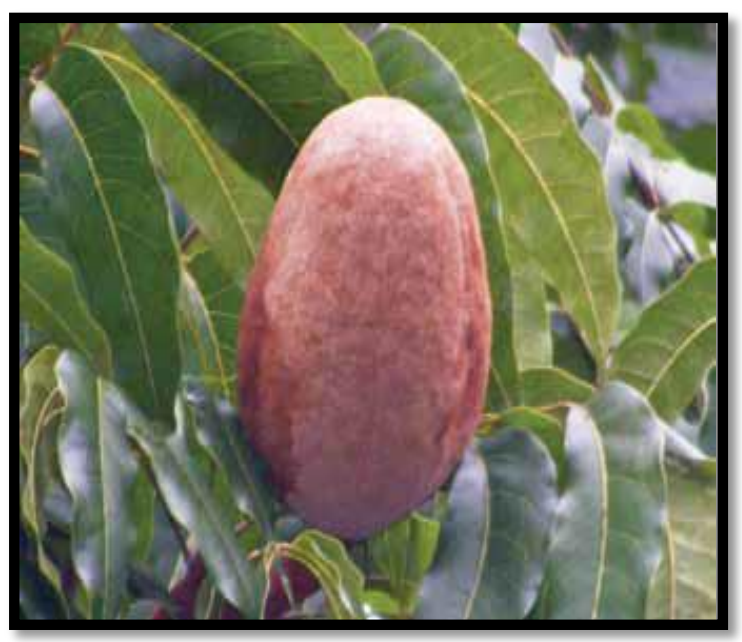

Fig-3: Brown fruit of Swietenia macrophylla trees (https://en.wikipedia.org/wiki/Swietenia_macrophylla) 


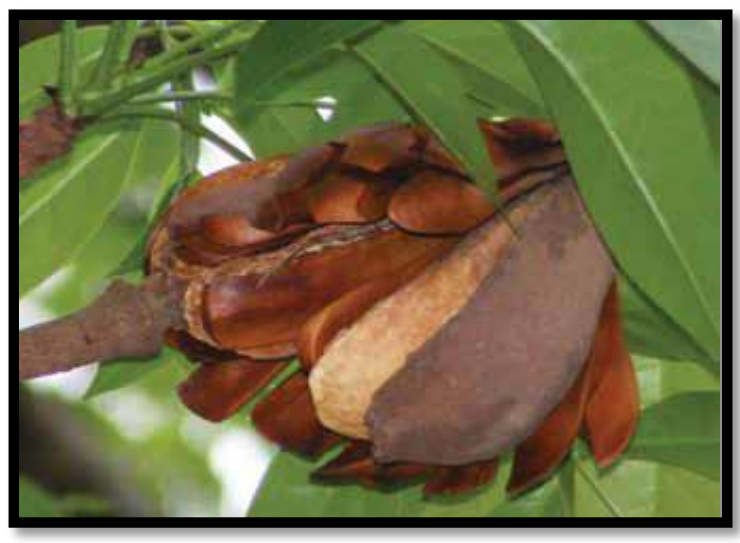

Fig-4: Capsule of Swietenia macrophylla trees (Internal arrangement of winged seeds) (https://en.wikipedia.org/wiki/Swietenia_macrophylla)

\section{Geographical distribution}

Swietenia macrophylla grows natively throughout the tropical regions of the Americas, in particular Central and South American countries such as Mexico and Bolivia and in west India, Malaysia, and southern China. It also grows naturally in Bolivia, Brazil, Colombia, Costa Rica, Ecuador, El Salvador, Guatemala, Honduras, Mexico, Nicaragua, Panama, Peru and Venezuela. However, it is nearly extinct in Ecuador, Colombia, Panama and Costa Rica; close to commercial extinction in Bolivia; declining in Mexico, Belize and Brazil; and in severe decline in Guatemala, Peru, Nicaragua and Honduras. The species has been extensively planted mainly in Southern Asia and the Pacific including India, Indonesia, Philippines and Sri Lanka. It has also been introduced into West Africa. (https://en.wikipedia.org/wiki/Swietenia_macrophylla).

\section{Ecological range}

Swietenia macrophylla can be found in a variety of forest types, from the edge of the pine savannah to the climax rainforest, but it is most commonly found in mixed hardwood forest belts, along riverbanks, and on fertile deep alluvial soils. It grows in small groups or scattered across the landscape, but numbers of more than 4-8 trees per hectare are uncommon.

Swietenia macrophylla may grow in a variety of soil types and environments. It has been found on alluvial soils, volcanic soils, heavy clays, lateritic soils, and soil formed from limestone, granite, and other sedimentary, igneous, or metamorphic rock formations within its natural range (Krisnawati et al., 2011).

It should not be planted in close proximity to sites with high conservation value. 5 Trees can grow in poor soils in Java plantations, but they thrive on deep, fertile, well-drained soils with a $\mathrm{pH}$ of 6.5-7.5. Swietenia macrophylla is now found naturally in both tropical dry and tropical wet forest types across the tropics. The ideal yearly rainfall within its ecological range is between 1000 and $2500 \mathrm{~mm}$, with a dry spell of 0-4 months.

Tropical dry forest conditions with annual precipitation of 1000-2000 $\mathrm{mm}$, a mean annual temperature of $24{ }^{\circ} \mathrm{C}$, and a potential evapo transpiration ratio of $1-2$ are reported to be ideal for this species' natural development. (https://en.wikipedia.org/wiki/Swietenia_macrophylla) ("The Plant List: A Working List of All Plant Species". Retrieved 20 December 2014). Table No. 1 showed Ecological Range of Swietenia macrophylla

Table-1: Ecological Range of Swietenia macrophylla

\begin{tabular}{|l|l|}
\hline Altitude & From sea level to $\mathbf{1 0 0 0} \mathbf{~ m}$ height. \\
\hline Soil & $\begin{array}{l}\text { Alluvial soils, volcanic soils, heavy clays, lateritic soils and soil derived from } \\
\text { limestone, granite and other sedimentary, igneous or metamorphic rock formations }\end{array}$ \\
\hline Rainfall & 1000 and $2500 \mathrm{~mm}$ \\
\hline Temperature & $24^{\circ} \mathrm{C}-35^{\circ} \mathrm{C}$. \\
\hline $\mathrm{Ph}$ & $6.5-7.5$ \\
\hline
\end{tabular}

\section{Wood characteristics}

Swietenia macrophylla is a medium-weight, soft wood. The sapwood is normally yellowish and the heartwood is reddish or pinkish, turning to a deep red or brown with age. It has a pleasing appearance, is simple to use with hand tools, and has great finishing properties and dimensional stability. It polishes well and does not fracture or bend, making it ideal for highend furniture production. The colour and workability of the wood are particularly prized. At $15 \%$ moisture content, the wood density ranges from 485 to 850 $\mathrm{kg} / \mathrm{m} 3$. The wood has an interlaced grain that is sometimes straight and has a fine to fairly gritty feel.
Because of the uneven grain, the surface is shiny, and the wood is frequently highly figured. Because it is easy to work and strong for its weight, it is well suited to a variety of applications, including light construction, boat building, musical instruments, models and pattern making, sawn or hewn building timbers, carpentry/joinery wall panelling, woodware, turnery, wood based materials, and plywood. (life.ku.dk and www.dfsc.dk). Table No. 2 showed Wood density of Swietenia macrophylla. Figure No. 6 showed Swietenia macrophylla timber. Figure No. 7 showed Items made of Swietenia macrophylla timber (a) Door pane (b) Cupboard (c) Flooring (d) Urn. 
Table-2: Wood density of Swietenia macrophylla

\begin{tabular}{|l|l|l|l|}
\hline \multicolumn{2}{|l|}{ Wood density $\left(\mathbf{k g} / \mathbf{m}^{3}\right)$} & Moisture Content \\
\hline Low & Medium & High & $\%$ \\
\hline 530 & 610 & 670 & 15 \\
\hline 485 & - & 840 & 12 \\
\hline 560 & - & 850 & 15 \\
\hline- & 500 & - & - \\
\hline 560 & - & 720 & 15 \\
\hline
\end{tabular}

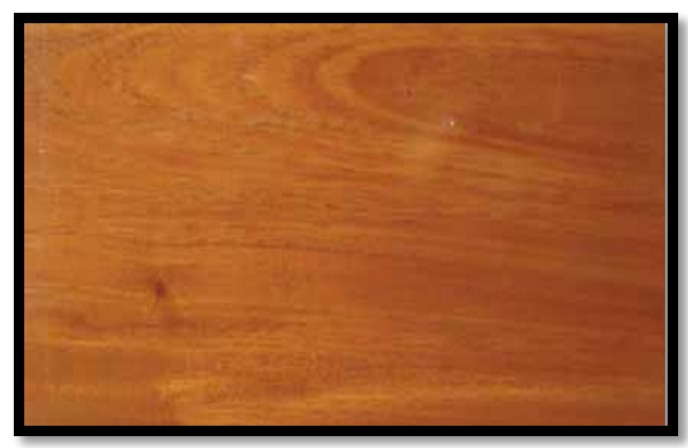

Fig-6: Swietenia macrophylla timber

(https://en.wikipedia.org/wiki/Swietenia_macrophylla)

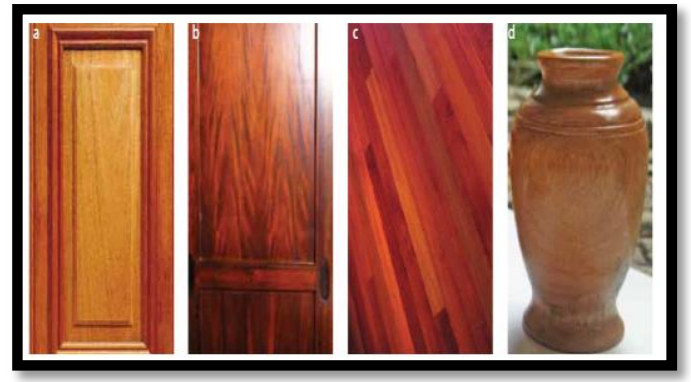

Fig-7: Items made of Swietenia macrophylla timber (a) Door pane (b) Cupboard (c) Flooring (d) Urn (https://en.wikipedia.org/wiki/Swietenia_macrophylla)

\section{Uses of Wood}

Because of its outstanding timber quality, Swietenia macrophylla is appropriate for large-scale timber production plantations. Construction materials, plywood (veneer), high-grade furniture, and cabinet building can all be made from the wood. Paneling, framing, flooring, automotive bodies, interior trim of boats, radio and phonograph cabinets, musical instrument bodies, mouldings, and other embellishments are all possible applications.

Swietenia macrophylla has a lot of potential for reforestation and afforestation, especially in terms of soil improvement. The tree species is recommended for revegetation of scrubland and denuded areas in the Philippines. It's also employed in agroforestry systems in Indonesia, such as maize, upland rice, and cassava in Java, and cassava, corn, peanuts, and pumpkin in our study village in South Kalimantan.

(https://en.wikipedia.org/wiki/Swietenia_macrophylla)

\section{CULTIVATION AND COLLECTION 7.1. Seed Production \& collection}

Seeds are used to propagate Swietenia macrophylla. The best results can be obtained by taking seeds from a mother tree that is in good shape and health. The amount of seed produced varies greatly from year to year. The fluctuation could be due to changes in flowering phenology or pollination or fertilisation failure. From 10 to 15 years of age, flowering and fruiting occur on a yearly basis. Seasons for flowering and fruiting vary depending on where you live.

The flowering season in Indonesia lasts from July to September, and the fruiting season lasts from December to February. When trees are leafless or just emerging into new leaf right before the rainy season, flowering occurs.

The fruits ripen in the dry season, when the trees lose some of their leaves and the warm air dries the fruits and encourages dehiscence. The fruits are best obtained from the ground right after seed fall or from the trees right before they open, either by climbing the trees or cutting down the seeds with poles with metal hooks. Fruit should be picked from the tree in the middle or near the end of the fruiting season. Just before the valves open and release the seeds, the pericarp turns a light coffee colour when the fruits are mature.

(https://en.wikipedia.org/wiki/Swietenia_macrophylla).

\subsection{Seed preparation}

Mature dry fruits or seeds (capsules) obtained from the forest floor can be stored in sacks for a few days without deteriorating significantly. To help unripe capsules to open, they may need to be dried first. In the sun, the capsules can be dried. To encourage capsules to open, they can be placed on a rack over electric lamps at a temperature of $38^{\circ} \mathrm{C}$ for $36-48$ hours. The amount of time it takes to dry a capsule is determined on its ripeness as well as the ambient temperature and humidity.

After drying for 1-4 days, depending on ripeness, the fruits split apart, and the seeds are easily removed by gentle shaking or raking of the fruits. To make handling easier and reduce volume, the seed wings are manually removed. The wing is broken $1 \mathrm{~cm}$ above the base, and the seeds are deposited in a container without wings. Table No. 3 showed 
Flowering and fruiting periods of Swietenia macrophylla (Selected countries).

Table-3: Flowering and fruiting periods of Swietenia macrophylla (Selected countries)

\begin{tabular}{|l|l|l|}
\hline Country & Flowering & Fruiting \\
\hline Central \& Northern South America & April-June & January-March \\
\hline Southern South America & September-October & July-August \\
\hline British Virgin Is. \& Puerto Rico & May-June & September-October \\
\hline Costa Rica & March-April & December-January \\
\hline Solomon Islands & - & June-September \\
\hline Philippines & March-June & December-March \\
\hline Indonesia & July-September & December-February \\
\hline
\end{tabular}

\subsection{Seed storage and viability}

Fresh Swietenia macrophylla seeds have an 80-90 percent viability rate, though this varies for stored seeds. The viability of seeds varies according to their size.

Swietenia macrophylla seed, according to Mayhew and Newton (1998), will not keep an appropriate level of viability if stored at room temperature and in humid circumstances for more than 3 months. When Swietenia macrophylla seeds are damp, they are susceptible to chilling damage below roughly $16{ }^{\circ} \mathrm{C}$. They must first be dried before being refrigerated. Dried seeds kept at $2-8{ }^{\circ} \mathrm{C}$ and steady humidity for more than a year have been reported to be viable. Deep freezing $\left(\right.$ at $-20^{\circ} \mathrm{C}$ ) will keep seeds viable for at least 2 years and maybe decades if they are dried to a moisture content of $5 \%$ or less.

\section{Propagation and planting}

\subsection{Sowing}

The seeds are planted in 3-7 cm deep furrows or holes in a light sand bed. Seeds should be germinated in the shade and kept wet. Depending on the desired size of the planting stock and whether or not transplanting is planned, the sowing density may vary.

Containers can also be used to grow Swietenia macrophylla. Growing stock in containers may result in a more fibrous root structure and better results when transplanted, but the cost may be prohibitive.

\subsection{Planting}

Weeds should be removed from all planting areas. Close spacing can help to shade the ground and so decrease weed development. Close spacing will also help to prevent the growth of aggressive lateral branches. Planting S. macrophylla normally requires a 2-3 m spacing. Figure No. 8 showed Swietenia macrophylla seedlings. Figure No. 9 showed Five-yearold $S$. macrophylla trees planted at a spacing of $4 \times 5 \mathrm{~m}$.

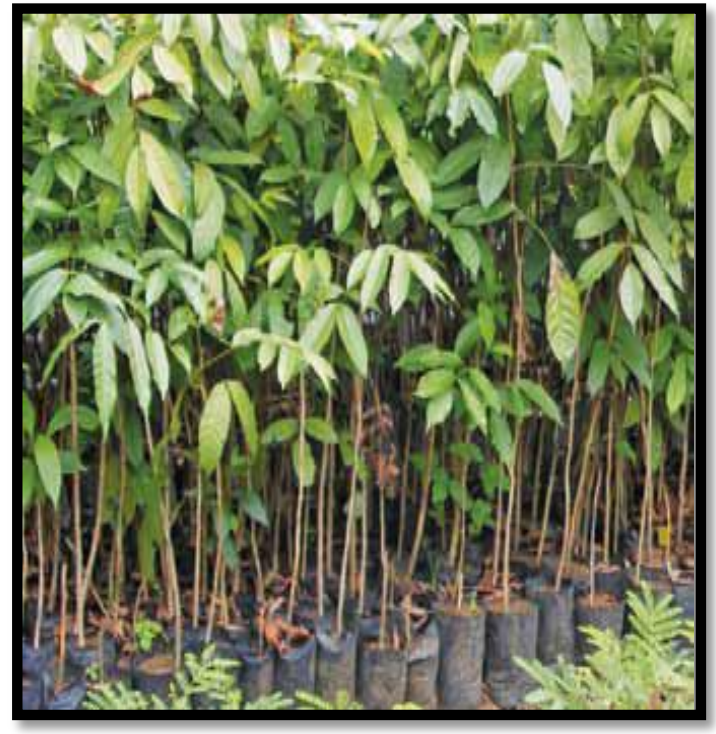

Fig-8: Swietenia macrophylla seedlings (https://en.wikipedia.org/wiki/Swietenia_macrophylla)

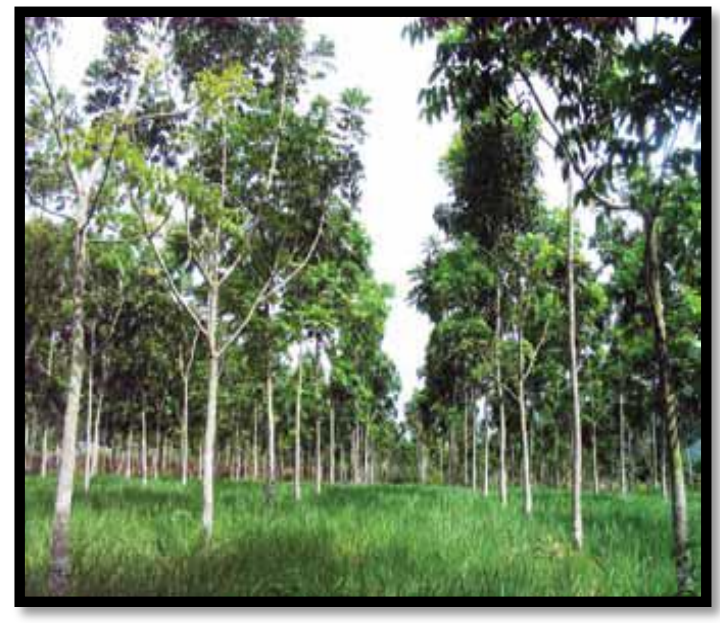

Fig-9: Five-year-old $S$. macrophylla trees planted at a spacing of $4 \times 5 \mathbf{~ m}$

(https://en.wikipedia.org/wiki/Swietenia_macrophylla)

\section{Plantation maintenance}

\subsection{Weeding}

Weeding is required to ensure maximum growth and survival of seedlings. Some weeds commonly found in young Swietenia macrophylla 
plantations are Imperata cylindrica Beauv., Clibadium surinamense L., Melastoma malabathricum L. and Merremia umbellate, Hallier.

\subsection{Fertilizing}

By changing the chemical composition of the apical shoots and/or promoting vigour, fertilising Swietenia macrophylla seedlings may reduce susceptibility to shoot borer damage and/or increase tolerance. Fertilizer is frequently given after planting in a ring around the seedlings at a quantity of 75-100 $\mathrm{g}$ NPK (chemical fertiliser) per plant.

\subsection{Replanting}

During the rotation, replanting can be done twice. The first replanting is usually done one month after planting to replace any dead seedlings, and the second is done at the end of the second year.

\section{Pruning}

Pruning is the process of eliminating dead or inactive branches from the lower trunk in order to promote the growth of clear wood. It also lowers the likelihood of illness and pest infestations (e.g. shoot borer). Pruning is often done for the first three years (Directorate of Industrial Plantation Forests 1990); this should be enough to lessen the threat of shoot borer because the moth primarily targets young trees. Pruning is best done shortly before the rainy season.

\subsection{Thinning}

The major goal of thinning is to improve the growth of the surviving trees so that they have a good form for the final crop. Diseased or pest-infested trees, deformed or poorly shaped trees, and repressed trees should all be considered for thinning. Selective removal of diseased trees may assist ensure that the final crop's seeds are genetically less prone to assault or more tolerant of it.

\section{Control of pests and diseases}

The shoot-borer Hypsipyla robusta is the most devastating pest in Swietenia macrophylla plantations. When terminal shoots display symptoms of dieback, which eventually results in deformed trees, attacks are most typically detected on saplings and polesize trees. The larvae dig into saplings' budding shoots, damaging the terminal bud and causing stem forking and growth retardation.

There is currently no effective way to control this insect. Shoot borer may be reduced by heavy trimming for the first three years following planting. $\mathrm{H}$. robusta infestation was averted in preliminary studies by growing Acacia mangium surrounding a $\mathrm{S}$. macrophylla plantation. Shoot-borer infestations were similarly reduced when neem (Azadirachta indica) was interplanted with S. macrophylla (Francis JK, 1991).

\section{Growth and yield}

For plantation planning, the capacity to anticipate the growth and yield potential of Swietenia macrophylla plantings is critical (Orwa et al., 2009).

\section{CONCLUSIONS}

It's vital that the nutrients from the miracle tree are used to a variety of uses. Swietenia macrophylla has anti-diabetic and anti-cancer properties. In order to better verify the benefits of Swietenia macrophylla, double-blind studies are less usual. The mechanism behind this irony has yet to be found. Environmental variables affecting the nutritional values of Swietenia macrophylla leaves and other parts grown around the world need to be looked into more thoroughly. A lot of vexing questions have yet to be answered. The wood of the plant is exploited on large scale by cultivators and peoples for making furniture and timber use. So, the tree should be exploited in large scale. So people should use this in less amount for timber and other commercial use.

\section{REFERENCES}

1. "The Plant List. (2014). A Working List of All Plant Species". Retrieved 20 December 2014

2. Ayyappadhas, R., Jestin, C., Kenneth, N., Dayana, N., \& Dhanalekshmi, U. M. (2012). Preliminary studies on antimicrobial activity of Swietenia macrophylla leaf extract. Int. J. Pharm. Sci. Rev. Res, 16, 1-4.

3. Bhurat, M. R., Bavaskar, S. R., Agrawal, A. D., \& Bagad, Y. M. (2011). Swietenia mahagoni Linn.-A phytopharmacological review. Asian J. Pharm. Res, 1(1), 1-4.

4. Chaudhary, K, Parihar, S, Sharma, D. 2021. A Critical Review on Nanoscience Advancement: In Treatment of Viral Infection. Journal of Drug Delivery and Therapeutics 11 (6), 225-237.

5. Divya, K., Pradeep, H. R., Kumar, K. K., Venkatesh, H. K., \& Jyothi, T. (2012). Herbal drug Swietenia mahagoni Jacq.-a review. Global Journal of Research on Medicinal Plants \& Indigenous Medicine, 1(10), 557.

6. Dutta, M. O. U. M. I. T. A., Raychaudhuri, U. T. P. A. L., Chakroborty, R. U. N. U., \& Maji, D. E. B. A. S. I. S. H. (2011). Role of diet and plants on diabetic patients-a critical appraisal. Science and Culture, 77(3-4).

7. Dutta, M. O. U. M. I. T. A., Raychaudhuri, U. T. P. A. L., Chakroborty, R. U. N. U., \& Maji, D. E. B. A. S. I. S. H. (2011). Role of diet and plants on diabetic patients-a critical appraisal. Science and Culture, 77(3-4).

8. Eid, A. M. M., Elmarzugi, N. A., \& El-enshasy, H. A. (2013). A review on the phytopharmacological effect of Swietenia macrophylla. seeds, 3, 5 .

9. Francis JK. 1991. Swietenia mahagoni Jacq, West Indies Mahogany: Meliaceae, Mahogany family. Washington, D.C.: U.S. Department of Agriculture, 
Forest Service, Southern Forest Experiment Station, Institute of Tropical Forestry.

10. Grandtner MM. Elsevier's dictionary of trees. London: Elsevier Science 2005; 1-381.

11. https://en.wikipedia.org/wiki/Swietenia_macrophyl la

12. Krisnawati, H., Kallio, M. H., \& Kanninen, M. (2011). Swietenia macrophylla King: ecology, silviculture and productivity. CIFOR.

13. life.ku.dk and www.dfsc.dk

14. Maiti, A., Dewanjee, S., \& Mandal, S. C. (2007). In vivo evaluation of antidiarrhoeal activity of the seed of Swietenia macrophylla King (Meliaceae). Tropical journal of pharmaceutical research, 6(2), 711-716.

15. Matsuse, I. T., Nakabayashi, T., Lim, Y. A., Hussein, G. M., Miyashiro, H., Kakiuchi, N., ... \& Shimotohno, K. (1997). A human immunodeficiency virus protease inhibitory substance from Swietenia mahagoni. Phytotherapy Research: An International Journal Devoted to Medical and Scientific Research on Plants and Plant Products, 11(6), 433-436.

16. Mohammed, S. B., Azhari, N. H., Mashitah, Y. M., Abdurahman, N. H., \& Mazza, A. S. (2014). Physicochemical characterization and antimicrobial activity of Swietenia macrophylla King seed oil. International Journal of Engineering Research, 3(3).

17. Orwa et al. Agroforestry Database 4.0 2009; Swietenia macrophylla

18. Parihar, S, Sharma, D. (2021). A Brief Overview on Crinum Latifolium. International Journal of Science and Research (IJSR), 10(12), 725-728.
19. Parihar, S., Sharma, D. (2021). A brief overview on Asparagus racemous. IJRAR, 8 (4), 96-108.

20. Parihar, S., Sharma, D. (2021). A brief overview on Vitis Vinifera. IJRAR, 10(12), 231-239.

21. Parihar, S., Sharma, D. (2021). Cynodondactylon: A Review of Pharmacological Activities. Sch Acad J Pharm 11, 183-189.

22. Parihar, S., Sharma, D. (2021). Navagraha (nine planets) plants: the traditional uses and the therapeutic potential of nine sacred plants of india that symbolises nine planets. IJRAR, 8(4), 96-108.

23. Sahgal, G., Ramanathan, S., Sasidharan, S., Mordi, M. N., Ismail, S., \& Mansor, S. M. (2009). Phytochemical and antimicrobial activity of Swietenia mahagoni crude methanolic seed extract. Tropical biomedicine, 26(3), 274-279.

24. Sahgal, G., Ramanathan, S., Sasidharan, S., Mordi, M. N., Ismail, S., \& Mansor, S. M. (2009). Phytochemical and antimicrobial activity of Swietenia mahagoni crude methanolic seed extract. Tropical biomedicine, 26(3), 274-279.

25. Telrandhe, U. B., Lokhande, R. R., Lodhe, V. N., Kosalge, S. B., Parihar, S., \& Sharma, D. (2021). Review on Herbal Drugs used in Dental Care Management. Asian Journal of Pharmaceutical Research and Development, 9(6), 71-79.

26. Parihar, S., Chattarpal, \& Sharma, D. (2022). Literature review on the list of plants used in the treatment of lung cancer. World journal of pharmacy and pharmaceutical sciences. 11(1). DOI: 10.20959/wjpps20221-21068. 